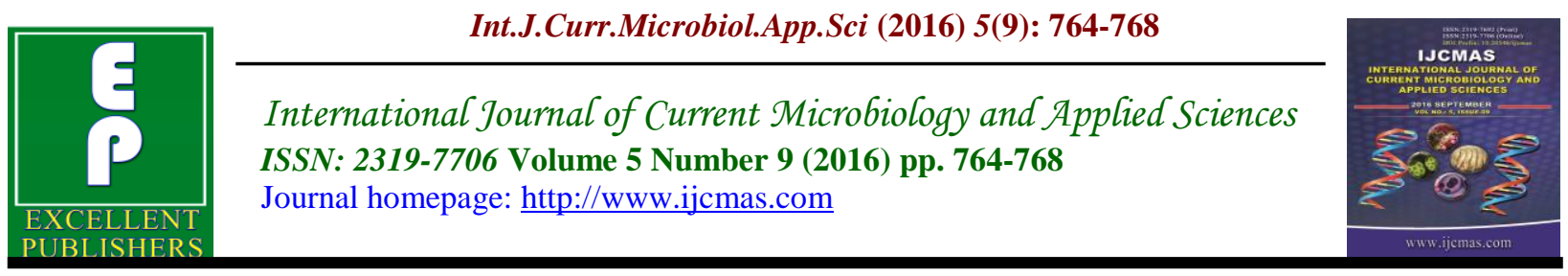

Original Research Article

http://dx.doi.org/10.20546/ijcmas.2016.509.087

\title{
In vitro Study on Anthelmintic Activity of Heterodermia boryi Macrolichen Collected from the Nilgiris, Tamilnadu, India
}

\author{
S. Senthil Prabhu* and S.S. Sudha \\ Postgraduate and Research Department of Microbiology, Dr.N.G.P. Arts and Science College \\ (Autonomous) Coimbatore - 641 048, Tamilnadu, INDIA \\ *Corresponding author
}

A B S T R A C T

Keywords Anthelmintic activity, Heterodermia boryi, Pheretima posthuma.

\begin{tabular}{l}
\hline Article Info \\
\hline Accepted: \\
30 August 2016 \\
Available Online: \\
10 September 2016
\end{tabular}

The aim of the present investigation was to evaluate the anthelmintic activity of Methanol, Acetone, Petroleum ether, Chloroform and Aqueous extracts of macrolichen Heterodermia boryi collected from western Ghats of Tamilnadu against Indian earthworm Pheretima posthuma. Various concentrations $(10-100 \mathrm{mg} / \mathrm{ml})$ of each extracts were tested in the bioassay, which involved determination of time of paralysis and time of death of the worms. Acetone and methanol extracts exhibited significant anthelmintic activity at highest concentration of $100 \mathrm{mg} / \mathrm{ml}$. Piperazine citrate $(10 \mathrm{mg} / \mathrm{ml})$ was included as standard reference and distilled water as control.

\section{Introduction}

Lichens are symbiotic organisms composed of a fungal partner (mycobiont) in association with one or more photosynthetic partners (photobiont). Lichens are important food source for many animals, and they do also play an important role for humans in some countries where they are part of their diet or used in traditional medicine (Upreti and Chatterjee, 2007). They usually grow on non-fertile ground, as well as epiphytes on the trees and leaves (Taylor et al., 1995). The total number of estimated species of lichens in India could vary between 2200 and 7200 species. Although inventorying of the Indian species of lichens is quite incomplete, India still emerges as the fifth richest country sharing $10.11 \%$ of species of lichens recorded in the world (Hans, 2003).

Lichens and lichen products have been used in traditional medicines for centuries and still hold considerable interest as alternative treatments in various parts of the world. In various systems of traditional medicine worldwide, including the Indian system of medicine, these lichen species are said to effectively cure dyspepsia, bleeding piles, bronchitis, scabies, stomach disorders, and 
many disorders of blood and heart (Saklani and Upreti, 1992; Lal and Upreti, 1995) Lichen synthesize numerous metabolites called lichen substances including aliphatic, cycloaliphatic, aromatic and terpenic components. These metabolites exert a wide variety of biological actions including antibiotic, antimycobacterial, immunomodulatory, antioxidant, cytotoxic, antiherbivore, and antitumour effects (Chand et al., 2009). lichens are rich source of antimicrobial agents (Senthil Prabhu and Sudha, 2015). The various extracts of the lichen have shown a good activity against helminths (Vinayaka and Archana, 2016).

Helminthic infestations are now being recognized as a cause of chronic ill health and sluggishness amongst the children. More than half of the population in the world suffers from worm infestations of one or the other. Helminthes also affect domestic animals and livestock causing considerable economic loss. Traditional system of medicine reports the efficacy of several natural products eliminating helminthes (Pal et al., 2007). Helminthic infections are among the most common infections in man, affecting a large proportion of the world's population. Today, the principal mode for control of gastrointestinal parasites is based on the commercial anthelmintics. Because of the increasing anthelmintic resistance and the impact of conventional anthelmintics on the environment, it is important to look for alternative strategies against gastrointestinal nematodes (Temjenmongla, 2005).

Considering the above facts this present study was investigated the Anthelmintic potentials of various solvent extract of Heterodermia boryi lichen species collected from western Ghats, The Nilgiris, Tamilnadu.

\section{Materials and Methods}

\section{Lichen Samples}

Lichen samples were collected from various sites of Western Ghats, The Nilgiris, Tamil Nadu, and India. The collected sample identified as Heterodermia boryi (Fée) Kr. P. Singh \& S.R. Singh, The identification of these lichens was done by performing morphological, anatomical and chemical tests (Culberson and Kristinsson, 1970; Awasthi, 2000a).

\section{Preparation of lichen Extracts}

The fine dry ground thalli of lichen $(50 \mathrm{~g})$ were subjected for extraction using soxhlet apparatus. The extracts were filtered and concentrated under reduced pressure in rotary shaker evaporator and stored at $4{ }^{\circ} \mathrm{C}$.

\section{Anthelmintic activity of solvent extract}

The Anthelmintic assay was carried as per the method of Pal et al., with minor modifications. The different concentrations of Solvent extracts of Heterodermia boryi were evaluated for anthelmintic activity using adult Indian earthworm (Pheretima pasthuma) model due to its anatomical and physiological resemblance with the intestinal roundworm parasite of human beings. different concentrations of solvent extract of lichen $(10,25,50$ and 100 $\mathrm{mg} / \mathrm{ml}$ ) were prepared in distilled water and poured into respective labelled petriplates. Six worms of nearly equal size were introduced into each of the plates. Observations were made for the time taken to paralysis and death of individual worm. Paralysis was said to occur when the worms were not able to move even in normal saline. Death was also confirmed by dipping the worms in slightly warm water. The mortality of parasite was assumed to have 
occurred when all signs of movement had cease. Piperazine citrate $(10 \mathrm{mg} / \mathrm{ml})$ was used as reference standard while water served as a control (Temjenmongla, 2005; Vinayaka and Archana, 2016).

\section{Statistical Analysis}

Data for anthelmintic study were expressed as mean \pm SD for 6 worms. All other data were expressed as mean of three independent analyses (Wayne, 2004).

\section{Results and Discussion}

In this study we have evaluated the effect of Heterodermia boryi extracts on earthworms. The extract showed significant wormicidal activity. Earthworms have the ability to move by ciliary movement. The outer layer of the earthworm is a mucilaginous layer and composed of complex polysaccharides. This layer being slimy, enables the earthworm to move freely. Any damage to the mucopolysaccharide membrane will expose the outer layer and this restricts its movement and can cause paralysis. This action may lead to the death of the worm by causing damage to the mucopolysaccharide layer. This causes irritation leading to paralysis followed by death of parasite. On introduction of extract to the worms there was slight excitory activity was observed but as the moment passes the worms were got fatigue and ultimately paralysed leading to their death. Helminthic infections are among the most common infections in man, affecting a large proportion of the world's population.

Table.1 Anthelmintic activity of different solvent extracts of Heterodermia boryi and standard drug (Piperazine citrate)

\begin{tabular}{|c|c|c|c|}
\hline Extract & Concentration & $\begin{array}{l}\text { Time taken for } \\
\text { paralysis } \\
(\mathrm{P}) \text { in min. }\end{array}$ & $\begin{array}{c}\text { Time taken for } \\
\text { death } \\
\text { (D) in min. }\end{array}$ \\
\hline $\begin{array}{l}\text { Control } \\
\text { (Water) }\end{array}$ & - & - & - \\
\hline Piperazine citrate & $10 \mathrm{mg} / \mathrm{ml}$ & $39 \pm 0.53$ & $48 \pm 0.30$ \\
\hline \multirow{4}{*}{ Methanol } & $10 \mathrm{mg} / \mathrm{ml}$ & $58 \pm 0.30$ & $90 \pm 0.51$ \\
\hline & $25 \mathrm{mg} / \mathrm{ml}$ & $45 \pm 0.30$ & $71 \pm 0.31$ \\
\hline & $50 \mathrm{mg} / \mathrm{ml}$ & $39 \pm 0.34$ & $63 \pm 0.42$ \\
\hline & $100 \mathrm{mg} / \mathrm{ml}$ & $21 \pm 0.14$ & $33 \pm 0.34$ \\
\hline \multirow{4}{*}{ Acetone } & $10 \mathrm{mg} / \mathrm{ml}$ & $42 \pm 0.00$ & $61 \pm 0.10$ \\
\hline & $25 \mathrm{mg} / \mathrm{ml}$ & $36 \pm 0.10$ & $56 \pm 0.13$ \\
\hline & $50 \mathrm{mg} / \mathrm{ml}$ & $30 \pm 0.34$ & $48 \pm 0.42$ \\
\hline & $100 \mathrm{mg} / \mathrm{ml}$ & $19 \pm 0.14$ & $31 \pm 0.25$ \\
\hline \multirow{4}{*}{ Petroleum ether } & $10 \mathrm{mg} / \mathrm{ml}$ & $68 \pm 0.20$ & $91 \pm 0.18$ \\
\hline & $25 \mathrm{mg} / \mathrm{ml}$ & $58 \pm 0.12$ & $78 \pm 0.53$ \\
\hline & $50 \mathrm{mg} / \mathrm{ml}$ & $47 \pm 0.30$ & $67 \pm 0.33$ \\
\hline & $100 \mathrm{mg} / \mathrm{ml}$ & $31 \pm 0.33$ & $40 \pm 0.13$ \\
\hline \multirow{4}{*}{ Chloroform } & $10 \mathrm{mg} / \mathrm{ml}$ & $69 \pm 0.38$ & $93 \pm 0.31$ \\
\hline & $25 \mathrm{mg} / \mathrm{ml}$ & $58 \pm 0.26$ & $86 \pm 0.23$ \\
\hline & $50 \mathrm{mg} / \mathrm{ml}$ & $49 \pm 0.17$ & $68 \pm 0.32$ \\
\hline & $100 \mathrm{mg} / \mathrm{ml}$ & $34 \pm 0.28$ & $46 \pm 0.32$ \\
\hline \multirow{4}{*}{ Aqueous } & $10 \mathrm{mg} / \mathrm{ml}$ & $72 \pm 0.30$ & $101 \pm 0.51$ \\
\hline & $25 \mathrm{mg} / \mathrm{ml}$ & $68 \pm 0.30$ & $79 \pm 0.51$ \\
\hline & $50 \mathrm{mg} / \mathrm{ml}$ & $58 \pm 0.34$ & $69 \pm 0.42$ \\
\hline & $100 \mathrm{mg} / \mathrm{ml}$ & $48 \pm 0.14$ & $59 \pm 0.34$ \\
\hline
\end{tabular}

Values are expressed as mean \pm SEM of three observations.

Parasitoses have been of concern to the medical field for centuries and the helminths still cause considerable problems for human beings and animals. During the past few 
decades, despite numerous advances made in understanding the mode of transmission and the treatment of these parasites, there are still no efficient products to control certain helminthes and the indiscriminate use of some drugs has generated several cases of resistance (Nunomura et al., 2006 ).

In this present investigation, different concentrations of various extracts lichen species shows significant anthelmintic activity. The earthworm selected for the anthelmintic activity was most sensitive to the acetone extract of Heterodermia boryi as can be seen in Table. 1. Dose-dependent paralysis ranging from loss of motility to loss of response to external stimuli, which eventually progressed to death. At 10, 25, 50 and $100 \mathrm{mg} / \mathrm{ml}$ concentrations paralysis was observed respectively at $42 \mathrm{~min}(10 \mathrm{mg} / \mathrm{ml})$, $36 \mathrm{~min}(25 \mathrm{mg} / \mathrm{ml}), 30 \mathrm{~min}(50 \mathrm{mg} / \mathrm{ml})$ and $19 \mathrm{~min}(100 \mathrm{mg} / \mathrm{ml})$ and death at $61 \mathrm{~min}(10$ $\mathrm{mg} / \mathrm{ml})$, $56 \mathrm{~min}(25 \mathrm{mg} / \mathrm{ml}) 48 \mathrm{~min}(50$ $\mathrm{mg} / \mathrm{ml})$ and $31 \mathrm{~min}(100 \mathrm{mg} / \mathrm{ml})$ postexposure. Methanol Extract of lichen species also exhibited dose-dependent anthelmintic activities that caused paralysis at $58 \mathrm{~min}(10$ $\mathrm{mg} / \mathrm{ml}) \quad 45 \mathrm{~min}(25 \mathrm{mg} / \mathrm{ml}) 39 \mathrm{~min}(50$ $\mathrm{mg} / \mathrm{ml}) 21 \mathrm{~min}(100 \mathrm{mg} / \mathrm{ml})$ and death at 90 $\min (10 \mathrm{mg} / \mathrm{ml}) 71 \mathrm{~min}(25 \mathrm{mg} / \mathrm{ml}) 63 \mathrm{~min}$ $(50 \mathrm{mg} / \mathrm{ml}) 33 \mathrm{~min}(100 \mathrm{mg} / \mathrm{ml})$ on post treatment. The Chloroform and Petroleum ether extracts also gives the significant activity aginst earthworm in minimum time exposure. Compare with the above solvent extracts acetone and methanol extracts of lichen showed higher anthelmintic activity. The Aqueous extract exhibits less activity than others (Table: 1).

The predominant effect of Piperazine citrate on worm is to cause a flaccid paralysis which results in expulsion of the worm by peristalsis. Piperazine citrate by increasing chloride ion conductance of worm muscle membrane produces hyper polarization and reduced excitability that leads to muscle relaxation and flaccid paralysis (Niezen et al., 1995). Different solvent extracts of Heterodermia boryi demonstrated both paralysis and death of worms especially at higher concentration of $100 \mathrm{mg} / \mathrm{ml}$ in nearly same time as compared to reference drug Piperazine citrate.

In conclusion, this preliminary investigation it has been concluded that the lichen Heterodermia boryi is having significant anthelmintic activity, the chemical constituent present in the lichen might be a responsible for this activity. Further research is in necessary to identify the compound responsible for this activity.

\section{References}

Awasthi, D.D. 2000a. A handbook of Lichens. Bishen Singh Mahendra Pal Singh, Dehra Dun, India.

Chand, P., Singh, M. and Rai Mayank. 2009. Antibacterial activity of some Indian Lichens. J. Ecophysiol. Occu. Health, 9: 23-29.

Culberson, C.F., Kristinsson, H. 1970. A standardized method for the identification of lichen products. $J$. Chromatography, 46: 85-93.

Hans Raj Negi. 2003. Lichens: A Valuable Bioresource for Environmental Monitoring and Sustainable Development. Resonance, 51-58.

In vitro studies of the anthelmintic activity of Picrolemma sprucei Hook.f. (Simaroubaceae). Acta Amazonica, 36(3): 327-330.

Lal, B., Upreti, D.K. 1995. Ethnobotanical notes on three Indian lichens. Lichenologist, 27: 77-79.

Niezen, J.H., Waghorn, T.S., Charleston, W.A.G., Waghorn, G.C. 1995. Growth and gastrointestinal nematode 
parasitism in lambs grazing either Lucerne (Medicago sativa) or sulla (Hedysarum coronarium), which contains condensed tannins. J. Agric. Sci., 125: 281-289.

Nunomura, R.C.S., E.C.C. daSilva, D.F. Oliverira, A.M. Garcia, J.N. Boeloni, S.M. Nunomura and A.M. Pohlit, 2006.

Pal, D.K., Sahoo, M., Mishra, A.K. 2007. Anthelminthic activity of stems of Opuntia vulgaris mill. Asian J. Chem., 19: 793-95.

Senthil Prabhu, S. and S.S. Sudha. 2015. Int. J. Adv. Res. Biol. Sci., 2(4): 177-181.

Saklani, A., Upreti, D.K. 1992. Folk uses of some lichens in Sikkim. $J$. Ethnopharmacol., 37: 229-233.

Taylor, T.N., Hass, H., Remy, W and Kerp, H. 1995. The oldest fossil lichen. Nature, 378: 244- 244.

Temjenmongla, Yadav, A.K. 2005.
Anticestodal efficacy of folklore medicinal plants of Naga tribes in Northeast India. Afr. J. Trad. CAM, 2(2): 129-133.

Upreti, D.K. and Chatterjee, S. 2007. Significance of lichens and theirsecondary metabolites: A review, In Fungi multifaceted microbes, (eds. Ganguli BN, Deshmukh SK), Anamaya Publishers, New Delhi, pp 169-188.

Vinayaka, S., Kanivebagilu, Archana, R. Mesta. 2016. Evaluation of Anthelmintic Activity of Lichen Usnea Undulata Stirt. (Parmeliaceae). Int. J. Res. Ayurveda Pharm., 7(3): 92-94.

Wayne, W.D. 2004. Biostatistics: A Foundation for the Analysis in the Health Science, 7th ed. Singapore, John Wiley and sons Asia Pvt Ltd;. p. 312.

\section{How to cite this article:}

Senthil Prabhu, S., and Sudha, S.S. 2016. In vitro Study on Anthelmintic Activity of Heterodermia boryi Macrolichen Collected from the Nilgiris, Tamilnadu, India. Int.J.Curr.Microbiol.App.Sci. 5(9): 764-768. doi: http://dx.doi.org/10.20546/ijcmas.2016.509.087 